\title{
A Rapid and Sensitive Detection of Aflatoxin-producing Fungus Using an Optimized Polymerase Chain Reaction (PCR)
}

\author{
Anong Bintvihok', Supitchaya Treebonmuang ${ }^{2}$, Kitiya Srisakwattana $^{2}$, Wisut Nuanchun ${ }^{2}$, \\ Koranis Patthanachai ${ }^{1}$ and Sungworn Usawang ${ }^{2}$ \\ ${ }^{1}$ Department of Veterinary Pharmacology, \\ ${ }^{2}$ Research and Development Center for Livestock Production Technology, Faculty of Veterinary Science, \\ Chulalongkorn University, Bangkok 10330, Thailand
}

(Received November 13, 2015; Revised December 20, 2015; Accepted January 7, 2016)

\begin{abstract}
Aflatoxin B1 (AFB1) is produced by Aspergillus flavus growing in feedstuffs. Early detection of maize contamination by aflatoxigenic fungi is advantageous since aflatoxins exert adverse health effects. In this study, we report the development of an optimized conventional PCR for AFB1 detection and a rapid, sensitive and simple screening Real-time PCR (qPCR) with SYBR Green and two pairs of primers targeting the aflR genes which involved aflatoxin biosynthesis. AFB1 contaminated maize samples were divided into three groups by the toxin concentration. Genomic DNA was extracted from those samples. The target genes for A. flavus were tested by conventional PCR and the PCR products were analyzed by electrophoresis. A conventional PCR was carried out as nested PCR to verify the gene amplicon sizes. PCR-RFLP patterns, obtained with Hinc II and Pvu II enzyme analysis showed the differences to distinguish aflatoxinproducing fungi. However, they are not quantitative and need a separation of the products on gel and their visualization under UV light. On the other hand, qPCR facilitates the monitoring of the reaction as it progresses. It does not require post-PCR handling, which reduces the risk of cross-contamination and handling errors. It results in a much faster throughout. We found that the optimal primer annealing temperature was $65^{\circ} \mathrm{C}$. The optimized template and primer concentration were $1.5 \mu \mathrm{L}(50 \mathrm{ng} / \mu \mathrm{L})$ and $3 \mu \mathrm{L}$ $(10 \mu \mathrm{M} / \mu \mathrm{L})$ respectively. SYBR Green qPCR of four genes demonstrated amplification curves and melting peaks for $t u b l$, afIM, afIR, and afID genes are at $88.0^{\circ} \mathrm{C}, 87.5^{\circ} \mathrm{C}, 83.5^{\circ} \mathrm{C}$, and $89.5^{\circ} \mathrm{C}$ respectively. Consequently, it was found that the four primers had elevated annealing temperatures, nevertheless it is desirable since it enhances the DNA binding specificity of the dye. New qPCR protocol could be employed for the determination of aflatoxin content in feedstuff samples.
\end{abstract}

Key words: Polymerase chain reaction, Aflatoxin-producing fungus, Nested PCR, PCR-RFLP, SYBR Green real-time PCR

Correspondence to: Anong Bintvihok, Department of Veterinary Pharmacology, Faculty of Veterinary Science, Chulalongkorn University, Henri Dunant Street, Pathumwan, Bangkok 10330, Thailand E-mail: anong_vet@yahoo.com

Abbreviations: AFB1, aflatoxin B1; PCR, Polymerase chain reaction; PCR-RFLP, Polymerase chain reaction-restriction fragment length polymorphism; qPCR, Real-time polymerase chain reaction; SYBR Green, Syber Green; DNA, Deoxy-nucleic acid; UV light, Ultra-violet light; A. flavus, Aspergillus flavus; A. parasiticus, Aspergillus parasiticus; ELISA, Enzyme-linked immunosorbent assay.

This is an Open-Access article distributed under the terms of the Creative Commons Attribution Non-Commercial License (http:// creativecommons.org/licenses/by-nc/3.0) which permits unrestricted non-commercial use, distribution, and reproduction in any medium, provided the original work is properly cited.

\section{INTRODUCTION}

Thailand is a humid tropical country thus various kinds of food and feedstuffs such as peanuts, maize, rice and other cereals are frequently contaminated with aflatoxins, which are mycotoxin produced by Aspergillus flavus (A. flavus) and Aspergillus parasiticus (A. parasiticus) (1). Aflatoxin $\mathrm{B} 1$ (AFB1) is a potent hepatotoxic and hepatocarcinogenic mycotoxin affecting humans and several animal species (27). The conventional methods for identifying and detecting fungi in foods and feedstuffs rely on morphological characteristics and the outcomes can be highly variable depending on the media and culture conditions. Furthermore, they are time consuming, labor intensive and require the expertise of 


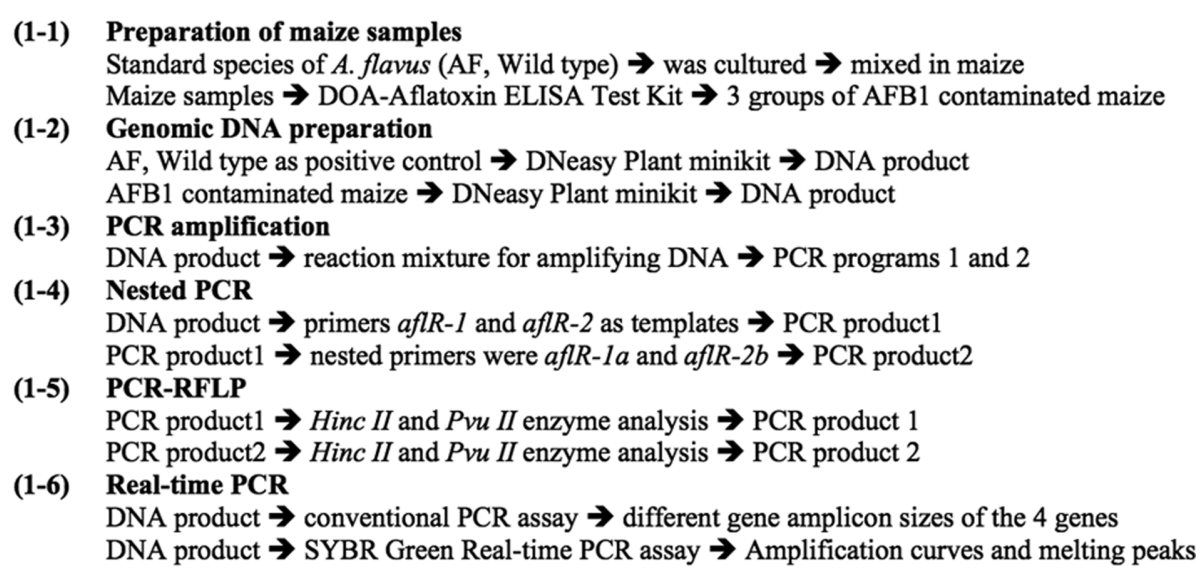

Fig. 1. Scheme of the experimental protocol.

mycologists. The disadvantages of highly advanced chemical methods for the analysis of aflatoxins, such as thin-layer chromatography, high performance liquid chromatography, gas liquid chromatography, and gas chromatography/mass spectrometry, include the requirement for highly sophisticated cleanup and/or derivatization procedures. Much simpler and faster immunological methods are available, but they, in turn, have the disadvantage of "one substance-one assay" setup. These methods include the immunoaffinity column chromatography, the radioimmunoassay, and ELISA (8-12). Recently, PCR-based methods have emerged as major tools for detection of aflatoxin-producing fungi in foods (13-15). In this direction, a DNA-based detection method such as PCR, Nested PCR, PCR-RFLP, qPCR are more sensitive, specific and have been employed for the detection of aflatoxigenic fungi. Therefore, the development of an optimized method for detection and identification of aflatoxigenic fungi in foods and feedstuffs is needed for the estimation and neutralization of the associated potential health risks. Accordingly, this research was undertaken to develop an optimized DNA-based conventional PCR for the detection of AFB1 and develop a rapid, sensitive and simple screening qPCR with SYBR Green.

\section{MATERIALS AND METHODS}

Preparation of maize samples. Standard species of $A$. flavus, which is a local strain obtained from the Department of Agriculture, Ministry of Agriculture and Cooperatives, Thailand (AF, wild type as positive control), was cultured on potato dextrose agar medium for seven days. The cultures were washed in distilled water, mixed with $30 \%$ moisture commercial Thai maize and kept in burlap or gunny bags for one to two weeks for AFB1 production (16). The inoculated maize samples were then evaporated and adjusted to $14 \%$ moisture. The maize samples were ground and analyzed for AFB1 by ELISA (DOA-Aflatoxin ELISA Test Kit) (17). The AFB1 contaminated maize samples were divided into three groups by the differences between toxin concentration (A, B $\&$ C) of 100, 20 and $0 \mu \mathrm{g} / \mathrm{kg}$, respectively (Fig. 1).

Genomic DNA preparation and PCR amplification. Genomic DNA, extracted from maize using DNeasy Plant minikit (Geneaid, USA) (Fig. 1) was used for conventional and Real-time PCR. Maize samples contaminated with AFB1 were ground and the extracted fungal DNA was analyzed by electrophoresis on $2 \%$ agarose gel with ethidium bromide. The gel image was then documented using UV transilluminator. DNA was stored at $-20^{\circ} \mathrm{C}$ until PCR amplification (18). PCR was performed to amplify the target fragments of aflatoxin-producing and control fungal genes. The reaction mixtures consisted of DNA template, dNTPs, Taq DNA polymerase, forward primer $(\mathrm{F})$, and reverse primer (R). Amplification of the fungal DNA was performed in a total reaction volume of $25 \mu \mathrm{L}$ and different PCR conditions for optimized PCR reaction (T1-T9), which contained extracted DNA from maize samples (Table 1 and Fig. 1). PCR amplification reactions for PCR programs 1 and 2 of each cycle consisted of pre-denaturation, denaturation, primer annealing, and extension, and followed by final extension. Subsequently, a total of 35 amplification cycles were carried out in a programmable thermocycler (Table 2 and Fig. 1).

Nested PCR. The nested PCR amplification was performed in two steps. The first step of PCR amplification was the reaction between primers $a f l R-1$ and $a f l R-2$ (Table 3 and Fig. 1). Then, PCR products from the first step were used as templates for the second step. The nested primers were $a f l R-1 \mathrm{a}$ and $a f l R-2 \mathrm{~b}$ with the same reaction conditions as the first step. Electrophoretic analysis of the PCR products 1 and 2 were performed at $100 \mathrm{~V}$ for $40 \mathrm{~min}$.

PCR-RFLP. The PCR products from conventional PCR in this study were subjected to restriction endonuclease Hinc II and Pvu II enzyme analysis to look for RFLP (Fig. 1). The DNA fragment amplified with primers was digested 
Table 1. The reaction mixture for amplifying DNA extracted from maize samples

\begin{tabular}{|c|c|c|c|c|c|c|c|c|c|c|}
\hline Mixture & Ref. & $\mathrm{T} 1$ & $\mathrm{~T} 2$ & $\mathrm{~T} 3$ & T4 & T5 & T6 & $\mathrm{T7}$ & T8 & T9 \\
\hline $\begin{array}{l}\text { 10xbuffer } \\
\text { dNTP }\end{array}$ & $2.5 \mu \mathrm{L}$ & $2.5 \mu \mathrm{L}$ & $2.5 \mu \mathrm{L}$ & $2.5 \mu \mathrm{L}$ & $\begin{array}{c}2.5 \mu \mathrm{L} \\
4 \mu \mathrm{L}\end{array}$ & $\begin{array}{c}2.5 \mu \mathrm{L} \\
4 \mu \mathrm{L}\end{array}$ & $\begin{array}{c}2.5 \mu \mathrm{L} \\
4 \mu \mathrm{L}\end{array}$ & $\begin{array}{c}2.5 \mu \mathrm{L} \\
4 \mu \mathrm{L}\end{array}$ & $2.5 \mu \mathrm{L}$ & $\begin{array}{c}2.5 \mu \mathrm{L} \\
4 \mu \mathrm{L}\end{array}$ \\
\hline Primer F & $0.5 \mu \mathrm{L}$ & $1 \mu \mathrm{M}$ & $1 \mu \mathrm{M}$ & $1 \mu \mathrm{M}$ & $1 \mu \mathrm{M}$ & $5 \mu \mathrm{M}$ & $5 \mu \mathrm{M}$ & $10 \mu \mathrm{M}$ & $10 \mu \mathrm{M}$ & $20 \mu \mathrm{M}$ \\
\hline Primer R & $0.5 \mu \mathrm{L}$ & $1 \mu \mathrm{M}$ & $1 \mu \mathrm{M}$ & $1 \mu \mathrm{M}$ & $1 \mu \mathrm{M}$ & $5 \mu \mathrm{M}$ & $5 \mu \mathrm{M}$ & $10 \mu \mathrm{M}$ & $10 \mu \mathrm{M}$ & $20 \mu \mathrm{M}$ \\
\hline Taq DNA & $0.5 \mu \mathrm{L}$ & $0.5 \mu \mathrm{L}$ & $0.5 \mu \mathrm{L}$ & $0.5 \mu \mathrm{L}$ & $0.5 \mu \mathrm{L}$ & $0.5 \mu \mathrm{L}$ & $0.5 \mu \mathrm{L}$ & $0.5 \mu \mathrm{L}$ & $0.5 \mu \mathrm{L}$ & $0.5 \mu \mathrm{L}$ \\
\hline Template & $1 \mu \mathrm{L}$ & $1 \mu \mathrm{L}$ & $2 \mu \mathrm{L}$ & $3 \mu \mathrm{L}$ & $5 \mu \mathrm{L}$ & $1 \mu \mathrm{L}$ & $2 \mu \mathrm{L}$ & $1 \mu \mathrm{L}$ & $2 \mu \mathrm{L}$ & $2 \mu \mathrm{L}$ \\
\hline Dist.water & $16 \mu \mathrm{L}$ & $16 \mu \mathrm{L}$ & $15 \mu \mathrm{L}$ & $14 \mu \mathrm{L}$ & $12 \mu \mathrm{L}$ & $16 \mu \mathrm{L}$ & $15 \mu \mathrm{L}$ & $16 \mu \mathrm{L}$ & $15 \mu \mathrm{L}$ & $15 \mu \mathrm{L}$ \\
\hline Total & $25 \mu \mathrm{L}$ & $25 \mu \mathrm{L}$ & $25 \mu \mathrm{L}$ & $25 \mu \mathrm{L}$ & $25 \mu \mathrm{L}$ & $25 \mu \mathrm{L}$ & $25 \mu \mathrm{L}$ & $25 \mu \mathrm{L}$ & $25 \mu \mathrm{L}$ & $25 \mu \mathrm{L}$ \\
\hline
\end{tabular}

Ref., Reference standard; T1-T9, different PCR conditions; Taq DNA, Taq DNA polymerase; Dist. water, Distilled water.

Table 2. PCR amplification reactions for PCR programs 1 and 2

\begin{tabular}{lll}
\hline \hline PCR cycle & Program 1 & Program 2 \\
\hline Pre-denaturation & $95^{\circ} \mathrm{C}, 10 \mathrm{~min}$ & $94^{\circ} \mathrm{C}, 5 \mathrm{~min}$ \\
Denaturation & $94^{\circ} \mathrm{C}, 30 \mathrm{sec}$ & $94^{\circ} \mathrm{C}, 30 \mathrm{sec}$ \\
Annealing & $50^{\circ} \mathrm{C}, 45 \mathrm{sec}$ & $50^{\circ} \mathrm{C}, 1.25 \mathrm{~min}$ \\
Extension & $72^{\circ} \mathrm{C}, 1.15 \mathrm{~min}$ & $72^{\circ} \mathrm{C}, 1.40 \mathrm{~min}$ \\
Final extension & $72^{\circ} \mathrm{C}, 10 \mathrm{~min}$ & $72^{\circ} \mathrm{C}, 10 \mathrm{~min}$ \\
\hline
\end{tabular}

with a restriction enzyme in the buffer recommended by the manufacturer with 20 40 $\mathrm{U}$ of enzyme per sample at $37^{\circ} \mathrm{C}$ for $4 \mathrm{hrs}$, with $10 \mu \mathrm{L}$ of PCR product in $50 \mu \mathrm{L}$ total volume. Electrophoretic analysis of all products was performed at $100 \mathrm{~V}$ for $40 \mathrm{~min}$.

Real-time PCR. Real time PCR is a technique used to monitor the progress of a PCR reaction in real time. The procedure was based on SYBR Green Supermix protocol. The target genes for A. flavus, their oligonucleotide primer pairs and their respective amplicon sizes were shown in Table 4 and Figs. 1 6. Specificity of set was tested by conventional PCR before detected by SYBR Green. The PCR product $(10 \mu \mathrm{L})$ was analyzed by electrophoresis on $2 \%$ agarose gel with ethidium bromide and the gel image was documented. A 100 bp size ladder was used as a marker to indicate the size of amplicons in SYBR Green qPCR assay. Evaluation of the optimized annealing template of DNA (1.5 $\mu \mathrm{L}$ and $2.5 \mu \mathrm{L}$, different each condition) and primer concentration $(1.5 \mu \mathrm{L}$ and $3 \mu \mathrm{L}$, different each condition) was carried out using an iQtm SYBR Green Supermix (BioRad Laboratories, Hercules, CA), according to the manufacturer's instructions. Amplification reactions were performed with $12.5 \mu \mathrm{L}$ of SYBR Green Supermix, $1 \mu \mathrm{L}$ of primers, 1.5 or $2.5 \mu \mathrm{L}$ of template DNA, 1.5 or $3 \mu \mathrm{L}$ of

Table 3. The oligonucleotide primers used for conventional PCR

\begin{tabular}{clllc}
\hline \hline No & Primers & Gene & Primer sequence (5'-3') & Amplicon size (bp) \\
\hline \multirow{2}{*}{1} & First PCR & $\begin{array}{l}\text { aflR-1 } \\
\text { aflR-2 }\end{array}$ & $\begin{array}{l}\text { AAC CGC ATC CAC AAT CTC AT } \\
\text { AGT GCA GTT CGC TCA GAA CA }\end{array}$ & $800 \mathrm{bp}$ \\
\hline \multirow{2}{*}{2} & \multirow{2}{*}{ Nested PCR } & $\begin{array}{l}\text { aflR-1a } \\
\text { aflR-2b }\end{array}$ & $\begin{array}{l}\text { GCA CCC TGT CTC CCC TAA CA } \\
\text { ACG ACC ATG CTC AGC AAG TA }\end{array}$ & $400 \mathrm{bp}$ \\
\hline
\end{tabular}

The first primers afIR-1 and afIR-2 and the nested primers aflR-1a and aflR-2b were used.

Table 4. The oligonucleotide primer pairs used for SYBR green real-time PCR amplifications

\begin{tabular}{clllc}
\hline \hline No & Primer pairs & Gene & Primer sequence (5'-3') & Annealing temperature \\
\hline \multirow{2}{*}{1} & Tubl-F & tubl & $\begin{array}{l}\text { GTC CGG TGC TGG TAA CAA CT } \\
\text { GGA GGT GGA GTT TCC AAT GA }\end{array}$ & 65 \\
\hline \multirow{2}{*}{2} & $\begin{array}{l}\text { Tubl-R } 1 \\
\text { Ver } 2\end{array}$ & \multirow{2}{*}{ aflM } & $\begin{array}{l}\text { GCC GCA CGC GGA GAA AGT GGT } \\
\text { GGG GAT ATA CTC CCG CGA CAC AGC C }\end{array}$ & 65 \\
\hline \multirow{2}{*}{3} & aflR 660 & aflR & $\begin{array}{l}\text { CGC GCT CCC AGT CCC CTT CAT T } \\
\text { CTT GTT CCC CGA GAT GAC CA }\end{array}$ & 59 \\
\hline \multirow{2}{*}{4} & nor 1249 & aflD & $\begin{array}{l}\text { ACC GCT ACG CCG GCA CTC TCG GCA C } \\
\text { GTT GGC CGC CAG CTT CGA CAC TCC G }\end{array}$ & 65 \\
\hline
\end{tabular}

The oligonucleotide primer pairs were used to target the specific fungal genes: Tub1-F and Tub1-R for tub1; Ver1 and Ver2 for afIM (versicolorin A); afIR 660 and afIR 1249 for afIR; nor1 and nor2 (norsolorinic acid) for afID. 
primer of each condition and deionized water was used to make up the total volume to $25 \mu \mathrm{L}$. The MiniOpticon RealTime PCR detection system (BioRad Laboratories, Hercules, CA) was performed at $95^{\circ} \mathrm{C}$ for $10 \mathrm{~min}$ followed by 35 cycles of initial denaturation at $94^{\circ} \mathrm{C}$ for $20 \mathrm{sec}$, primer annealing of $65^{\circ} \mathrm{C}$ for $30 \mathrm{sec}$ and primer extension of $72^{\circ} \mathrm{C}$ for $30 \mathrm{sec}$ with the final holding temperature of $4^{\circ} \mathrm{C}$. Fluorescence was measured during the annealing step of each cycle.

\section{RESULTS}

Genomic DNA preparation from contaminated material and PCR amplification. The DNA was assessed and quantified using $2 \%$ agarose gel then the good genomic DNA was isolated from all groups (AF, A, B \& C). The PCR amplification conditions of programs 1 and 2 were compared based on the electrophoretic banding patterns of PCR products (Table 1 and 2). The optimal PCR conditions in T1-T9 were shown in Fig. 2A and 2B. In this study, the PCR condition of program 2 gave the best results and the PCR conditions T5-T9 can be used as good PCR conditions.

Analysis of fungal genes by nested PCR. Nested PCR was performed using primers $a f l R-1 \mathrm{a}$ and $a f l R-2 \mathrm{~b}$. The PCR product from amplification with primers aflR-1 and aflR-2 was used as template. Electrophoretic analysis of the PCR

\section{(A)}

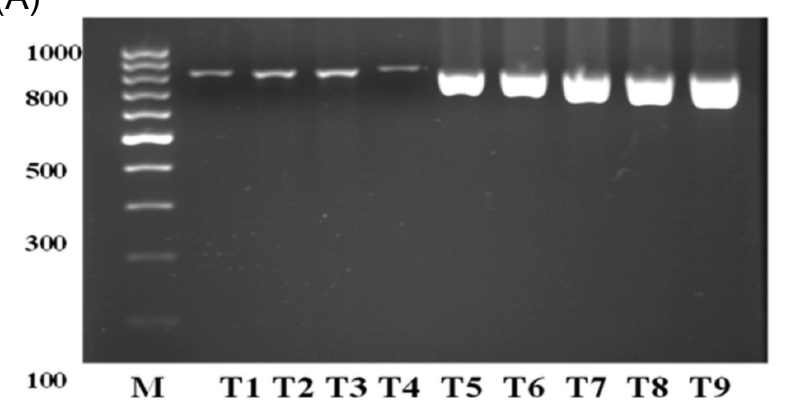

(B)

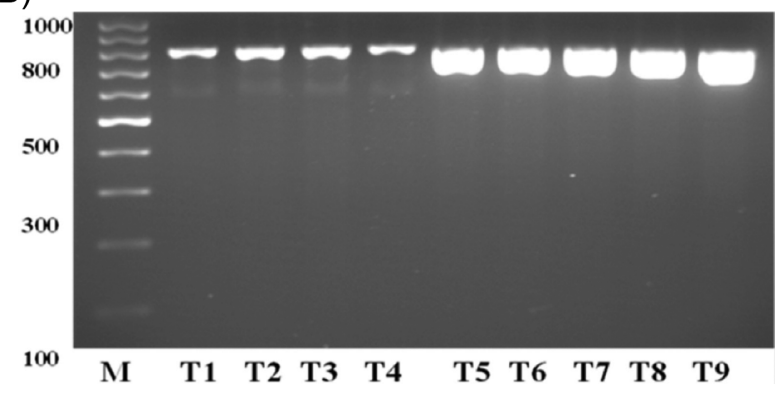

Fig. 2. Electrophoresis banding pattern after $P C R$ amplification with program 1 (A) and program 2 (B). Lane M, 100 bp DNA ladder standard; T1-T9, different PCR conditions. The amplified DNA fragment sizes $(830 \mathrm{bp})$ were estimated after comparison with a commercial 100 bp DNA ladder. The PCR amplification program 2 gave the best results. products was performed at $100 \mathrm{~V}$ for $40 \mathrm{~min}$. The results were shown that the DNA could be detected PCR product 1 from wild type (AF) and group A, B \& C (Table 3 and Fig. $3 \mathrm{~A})$. Electrophoretic banding patterns of nested PCR products obtained after amplification with primers aflR-1a and $a f l R-2 \mathrm{~b}$ are given in Fig. 3B. The sizes of the resulting DNA fragments were estimated after comparing with a commercial 100 bp DNA ladder.

PCR-RFLP analysis. Restriction fragment length polymorphism (RFLP) based analysis was a technique used for genotyping. DNA sequence polymorphisms display different migration profiles from wild-type fragment patterns when DNA was digested with restriction fragments in product 1, nested PCR (product 2) and separated by electrophoresis. The DNA fragment sizes were estimated after comparison with a commercial 100 bp DNA ladder.

PCR product 1 digestions with Hinc II and Pvu II was performed to enable restriction site distribution analysis, were shown $5(150,200,250,400,800 \mathrm{bp})$ and $4(150,200$,

(A)

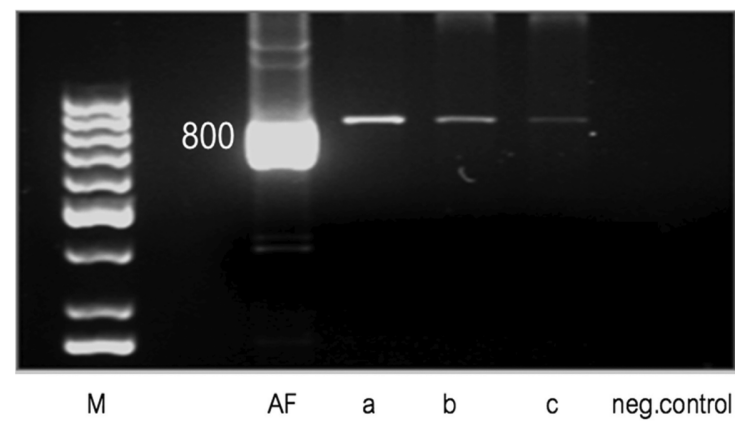

(B)

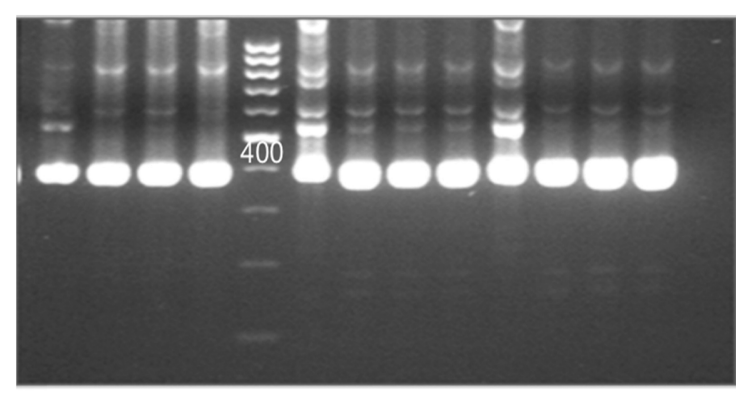

$\begin{array}{lllllllllllll}\text { a1 } & \text { a2 } & \text { a3 } & \text { a4 } & \text { M } & \text { b1 } & \text { b2 } & \text { b3 } & \text { b4 } & \text { c1 } & \text { c2 } & \text { c3 } & \text { c4 }\end{array}$

Fig. 3. Electrophoresis banding pattern of PCR product 1 after amplification with primers aflR-1 and aflR-2 (A) and PCR product 2 after the nested PCR amplification with primers aflR-1a and aflR-2b (B). (A) Lane M, 100 bp DNA ladder standard; AF, positive control; $a$, b \& $C$, sample groups $A, B$ \& $C$ respectively. The amplified DNA fragment sizes (800 bp) were estimated after comparison with a commercial 100 bp DNA ladder. (B) Lane M, 100 bp DNA ladder standard; a1-a4, b1-b4, c1-c4, sample groups A, B \& C respectively. The amplified DNA fragment sizes (400 bp) were estimated after comparison with a commercial $100 \mathrm{bp}$ DNA ladder. 
(A)

(B)
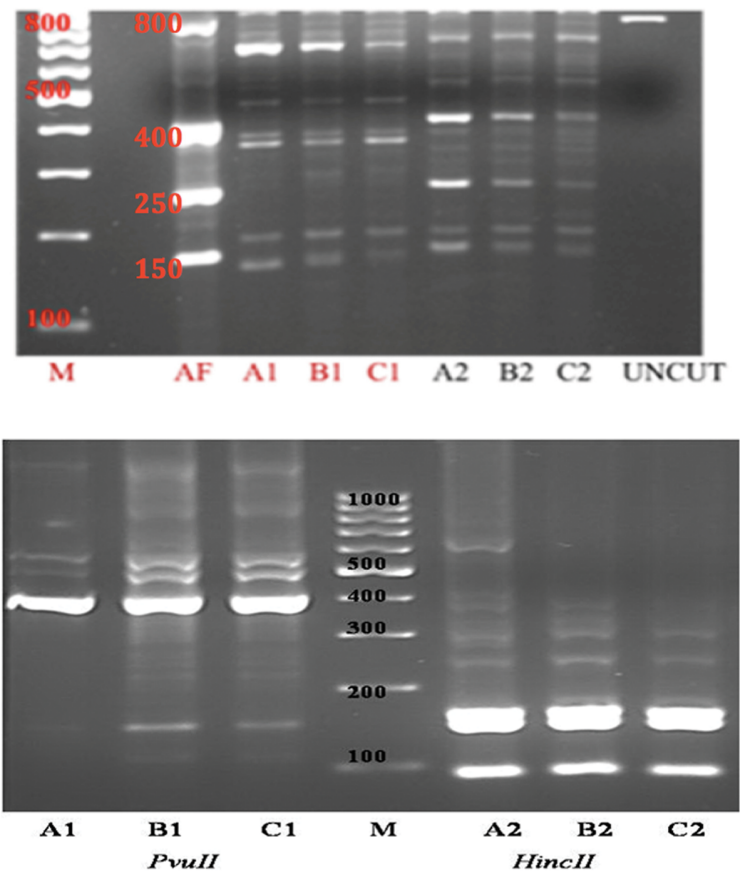

(C)

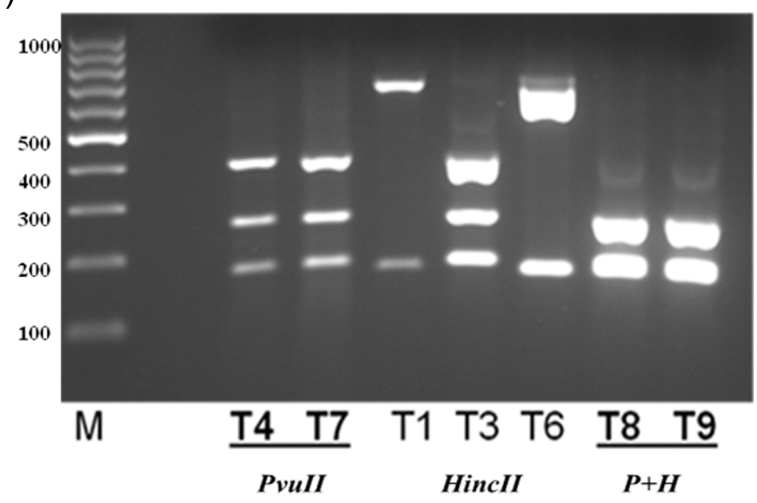

Fig. 4. Electrophoresis banding pattern after PCR product 1 (A), PCR product 2 (B) and double (C) digestions with Hinc II and Pvu II. (A) Lane M, 100 bp DNA ladder standard; AF, positive control (4 PCR-based detection); $\mathrm{A} 1, \mathrm{~B} 1 \& \mathrm{C} 1$, products of digestion with Pvu II (4 PCR-based detection); A2, B2 \& C2, products of digestion with Hinc II (5 PCR-based detection); UNCUT, native PCR product. (B) Lane $M, 100$ bp DNA ladder standard; A1, B1 \& $\mathrm{C} 1$, products of digestion with Pvu II (3 PCR-based detection); A2, B2 \& C2, products of digestion with Hinc II (2 PCR-based detection). (C) Lane M, 100 bp DNA ladder standard; T4 \& T7, products of digestion with Pvu II; T1, T3 \& T6, products of digestion with Hinc II. The digestion conditions were essentially the same as for single digests, except that 20 units of Hinc II and 40 units of Pvu II were used in $2 \times$ concentrated buffer, T8 and T9 (2 PCR-based detection).

380, 700 bp) PCR-based detection, respectively (Fig. 4A). The resulting fragments were separated by electrophoresis from PCR product 2 digestions with Hinc II and Pvu II were shown specific banding of $2(100,150 \mathrm{bp})$ and 3 (100,
(A)

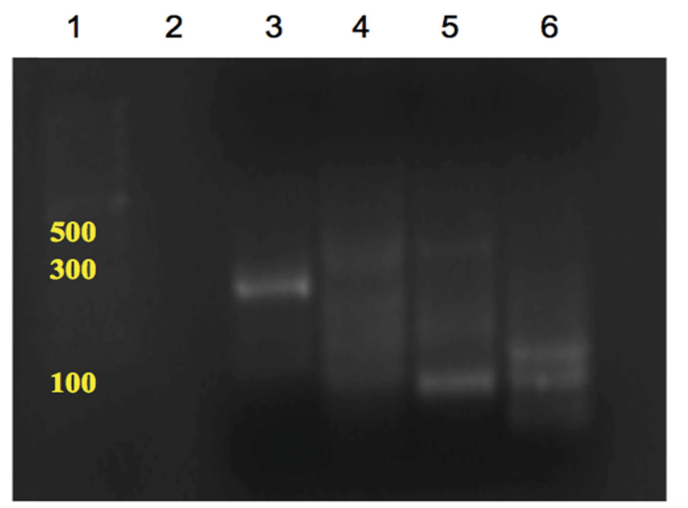

(B)

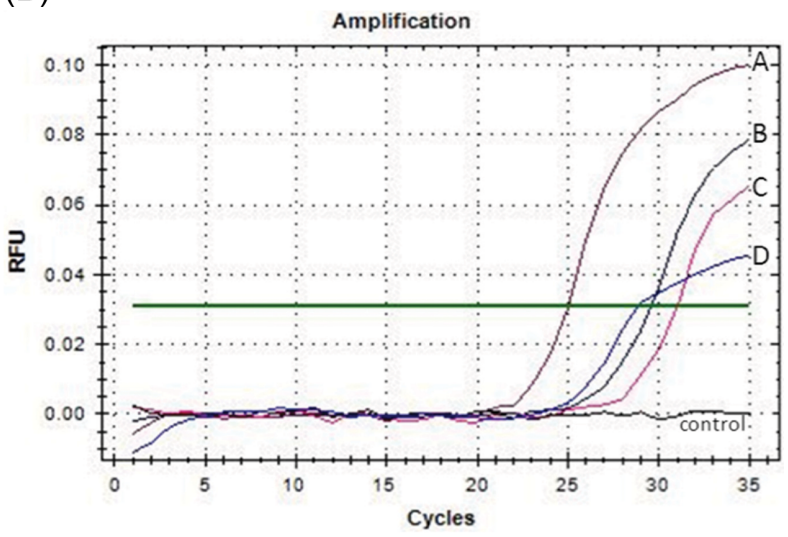

(C)

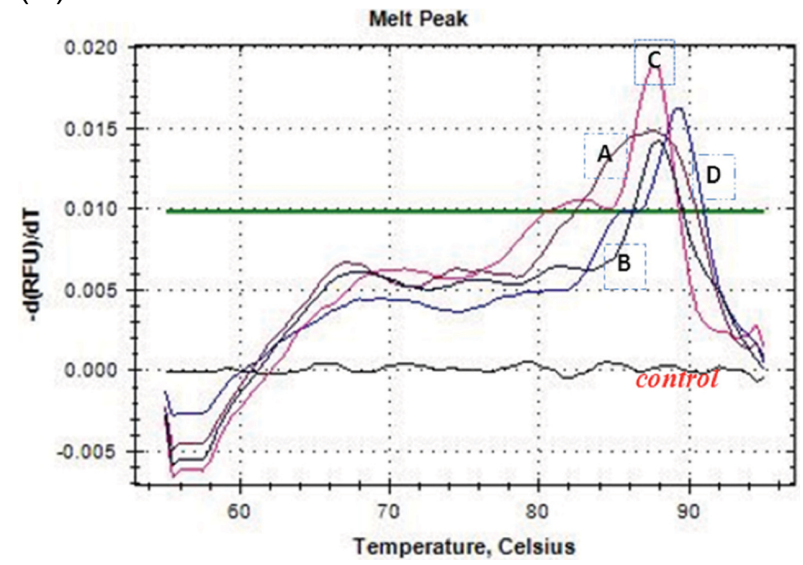

Fig. 5. Electrophoresis banding patterns of the amplified gene products after electrophoresis on $2 \%$ agarose gel (A), amplification curves (B) and melting peaks $(C)$ for the four genes, (tub1, afIM, afIR, and afID) after Real-time PCR with SYBR Green. (A) Lane 1, 100 bp DNA ladder standard; Lane 2, no template; Lane 3 , tub1 (the fungal $\beta$-tubulin gene as a positive fungal control); Lane 4, afIM; Lane 5, afIR; Lane 6, afID. Primer set specificity was tested by conventional PCR before detected by SYBR Green. (B,C) A, afIM; B, tub1 (positive control); C, afIR; D, afID and control, no template as negative control.

150, 400 bp) PCR-based detection, respectively (Fig. 4B). PCR-RFLP patterns obtained with these two enzymes 
showed adequate differences to distinguish the aflatoxinproducing fungus from controls. The conditions for double digestion reactions were essentially the same for both enzymes, except that 20 units of Hinc $I I$ and 40 units of $P v u$ II were used in $2 \times$ concentrated buffer, T8 and T9 (Fig. $4 \mathrm{C})$. The sizes of the resulting DNA fragments were estimated after comparing with a commercial 100 bp DNA ladder.

Real-time PCR ( $(\mathbf{P C R})$ analysis. Sample DNA concentrations were determined using Genesys 10 series spectrophotometer (Thermo Fisher Scientific). The purity of the extracted DNA was between 1.6 and 1.9. The samples were then diluted to a final DNA concentration of $50 \mathrm{ng} / \mu \mathrm{L}$. The target genes for A. flavus, the specific oligonucleotide primer pairs, and their respective amplicon sizes are shown in Table 4. Primer set specificity was tested by conventional $\mathrm{PCR}$, which was carried out to assess the different gene amplicon sizes (Fig. 5A). PCR products (about $10 \mu \mathrm{L}$ ) were analyzed by electrophoresis on $2 \%$ agarose gel with ethidium bromide, and the gel image was then documented. A commercial $100 \mathrm{bp}$ DNA ladder was used as a marker to determine the amplicon sizes. Evaluation of the optimal volume of the annealing DNA template $(1.5 \mu \mathrm{L}$ or $2.5 \mu \mathrm{L})$ and optimal primer concentrations $(1.5 \mu \mathrm{L}$ or $3 \mu \mathrm{L})$ was carried out using iQtm SYBR Green Supermix (BioRad Laboratories, Hercules, CA), according to the manufacturer's instructions. Amplification reactions were performed with $12.5 \mu \mathrm{L}$ SYBR Green Supermix, $1 \mu \mathrm{L}$ primers, 1.5 or $2.5 \mu \mathrm{L}$ template DNA, 1.5 or $3 \mu \mathrm{L}$ primers for each condition, and deionized water added to a final volume of $25 \mu \mathrm{L}$. MiniOpticon Real-Time PCR detection system (BioRad Laboratories, Hercules, CA) was used and the PCR reaction was performed at $95^{\circ} \mathrm{C}$ for $10 \mathrm{~min}$, followed by 35 cycles of initial denaturation at $94^{\circ} \mathrm{C}$ for $20 \mathrm{sec}$, primer annealing of $65^{\circ} \mathrm{C}$ for $30 \mathrm{sec}$, and primer extension of $72^{\circ} \mathrm{C}$ for $30 \mathrm{sec}$, with the final holding temperature of $4^{\circ} \mathrm{C}$. Fluorescence was measured during the annealing step of each cycle. The aflatoxin regulatory gene $(a f l R)$ was involved in the regulation of aflatoxin biosynthesis and the gene sequence has been published (19). We herein adapted and validated a Real-time PCR procedure based on the SYBR Green protocol with two primer pairs that targeted the aflR genes. We found that the optimal annealing primer temperature was $65^{\circ} \mathrm{C}$. SYBR Green Real-time PCR for the quantification of the four genes gave reproducible amplification curves. The melting curves for the individual genes are given in Fig. 5B and 5C. The melting peak temperature for tubl was $88.0^{\circ} \mathrm{C}, 87.5^{\circ} \mathrm{C}$ for $a f l M, 83.5^{\circ} \mathrm{C}$ for aflR, and $89.5^{\circ} \mathrm{C}$ for aflD, respectively.

\section{DISCUSSION}

Early detection of contamination of maize by aflatoxigenic fungi is extremely useful because aflatoxins exert adverse health effects (20). In this report, we developed highly specific methods that allow the detection of $A$. flavus in Thai maize samples. Conventional PCR was carried out as nested PCR to describe the gene amplicon size of all 4 groups (Fig. 3A, 3B and Table 3). PCR-RFLP patterns obtained with these two enzymes showed sufficient differences to distinguish aflatoxin-producing fungi, that patterns might show the genetic similarly among the other groups of this section (Fig. 4A, 4B and 4C). We found that, there are several limitations in conventional PCR assays. For example, they are not quantitative and need a separation of the products on gel and their visualization under UV light. Real-time PCR is a technique used to monitor the progress of a PCR reaction in real time. It can be used to quantify a relatively small amount of a PCR product obtained from DNA, cDNA or RNA templates. Real-time PCR is based on the detection of fluorescence of a reporter molecule, which increases as the reaction proceeds. This increase in the fluorescent signal occurs due to the accumulation of the PCR product with each amplification cycle. Fluorescent reporter molecules include dyes that bind to the doublestranded DNA (i.e. SYBR ${ }^{\circledR}$ Green). Real-time PCR facilitates the monitoring of a reaction as it progresses (21). It does not require post-PCR handling, which reduces the risk of cross-contamination and handling errors. These features result in a much higher throughout than other detection methods (22).

The present study was designed to optimize the detection of aflatoxin-producing fungi in maize. The detection of the amplified template was accomplished with SYBR Green. This revealed that the four primers had a high annealing temperature. This high annealing temperature is desirable because it enhances DNA dye binding specificity, prevents inhibition and primer-dimer formation (23). The amplification of the PCR product is detected by monitoring the fluorescence of non-specific stains, such as SYBR Green, which bind double stranded DNA (24). The melting profile of the PCR products is then checked at the end of the reaction to verify the specificity of the amplification reaction (25). We optimized the Nested PCR, PCR-RFLP and Realtime PCR assays for the detection of the aflatoxin-producing fungi in Thai maize. We developed highly specific methods that allow the detection of aflatoxigenic fungi species, i.e., A. flavus in sample maize feedstuffs. In addition, we developed and optimized a Real-time PCR assay with SYBR Green (Table 4, Fig. 5A, 5B and 5C). The key steps of the PCR reaction optimization included the adjustment of primer and template concentrations, and the reaction performance with the annealing temperature of $65^{\circ} \mathrm{C}$. We found that the optimal template concentration was $1.5 \mu \mathrm{L}(50 \mathrm{ng} /$ $\mu \mathrm{L})$ and the optimal primer concentration was $3 \mu \mathrm{L}$ $(10 \mu \mathrm{M} / \mu \mathrm{L})$, respectively.

The PCR methods outlined in this study may play an important role in the future quality and safety procedures in 
the food and feed industry.

\section{ACKNOWLEDGEMENTS}

The authors wish to express our appreciation to Research and Development Center for Livestock Production Technology, Faculty of Veterinary Science, Chulalongkorn University for graciously providing funds.

\section{REFERENCES}

1. Yoshizawa, T., Yamashita, A. and Chokethaworn, N. (1996) Occurrence of fumonisins and aflatoxins in corn from Thailand. Food Addit. Contam., 13, 163-168.

2. Bhat, R.V. (1991) Aflatoxin: successes and failures of three decades of research in Fungi and Mycotoxins in Stored Products (Champ, B.R., Highley, E., Hocking, A.D. and Pitt, J.I. edition). ACIAR Proc., 36, 80-85.

3. Norred, W.P. (1986) Occurrence and clinical manifestations of aflatoxicosis in Diagnosis of Mycotoxicosis (Richard, J.L. and Thurston, J.R. edition). Martinus Nijhoff, Dordrecht, pp. 1129.

4. Pitt, J.L. and Hocking, A.D. (1985) Fungi and food spoilage, Academic Press, Australia, pp. 259-311.

5. Bintvihok, A., Kiatipattanasakul, W. and Doi, K. (1997) Acute toxicity of aflatoxin B1 in three species of domestic fowls. $J$. Toxicol. Pathol., 10, 149-152.

6. Bintvihok, A., Shoya, S., Nagasawa, S., Sato, M. and Sutherat, S. (1991) Effects of aflatoxin B1 in ducklings: effect on liver lesions in Fungi and Mycotoxins in Stored Products (Champ, B.R., Highley, E., Hocking, A.D. and Pitt, J.I. edition). ACIAR Proc., 36, pp. 233-235.

7. Bintvihok, A., Nagasawa, S. and Hayashi, M. (1991) Effects of aflatoxin B1 in ducklings: effect on hepatic microsomal drug metabolizing enzyme in Fungi and Mycotoxins in Stored Products (Champ, B.R., Highley, E., Hocking, A.D. and Pitt, J.I. edition). ACIAR Proc., 36, pp. 230-232.

8. Pitt, J.L., Hocking, A.D. and Glenn, D.R. (1983) An improved medium for the detection of Aspergillus flavus and A. parasiticus. J. Appl. Bacteriol., 54, 109-114.

9. Sugano, K., Bintvihok, A., Thanacharoenwatch, P., Sookthinthai, L. and Intraraksa, R. (1993) Simple and rapid cleanup method for determination of aflatoxin B1 in mixed feed by sep-pak florisil cartridge. Proc. Jpn. Assoc. Mycotoxicol., 37, 43-45.

10. Chu, F.S., Fan, T.S., Zhang, G.S., Xu, Y.C., Faust, S. and McMahon, P.L. (1987) Improved enzyme-linked immunosorbent assay for aflatoxin B1 in agricultural commodities. $J$. Assoc. Off. Anal. Chem., 70, 854-857.

11. Hirano, K., Adachi, Y., Bintvihok, A., Ishibashi, S. and Kumazawa, N.H. (1992) An improved method for extraction and cleanup of aflatoxin B1 from liver. J. Vet. Med. Sci., 54, 567-569.

12. Hirano, K., Adachi, Y., Ishibashi, S., Sueyoshi, M., Bintvihok, A. and Kumazawa, N.H. (1991) Detection of aflatoxin B1 in plasma of fowl receiving feed naturally contaminated with aflatoxin B1. J. Vet. Med. Sci. 53, 1083-1085.

13. Shapira, R., Paster, N., Eyal, O., Menasherov, M., Matt, A. and Salomon, R. (1996) Determination of aflatoxigenic molds in grains by PCR. Appl. Environ. Microbiol., 62, 3270-3273.

14. Levin, R.E. (2012) PCR detection of aflatoxin producing fungi and its limitations. Int. J. Food Microbiol., 156, 1-6.

15. Rodriguez, A., Rodríguez, M., Luque, M.I., Martin, A. and Córdiba, J.J. (2012) Real-time PCR assays for detection and quantification of aflatoxin-producing molds in foods. Food Microbiol., 31, 89-99.

16. Bintvihok, A., Thiengnin, S., Patchimasiri, T., Thummabood, S., Shoya, S., Ogura, Y., Kumagai, S. and Doi, K. (1993) Toxic effects of dietary aflatoxin and its residue in tissues and eggs in laying quails. Proc. the 11th Int. Symposium of the World Association of Veterinary Food Hygienists (WAVFH), pp. 299-307.

17. Chinaphuti, A., Trikarunasawat, C., Wongurai, A. and Kositcharoenkul, S. (2002) Production of in-house ELISA test kit for detection of aflatoxin in agricultural commodities and their validations. Kasetsart J. Nat. Sci., 36, 179-186.

18. Bintvihok, A., Treebonmuang, S., Patthanachai, K., Srisakwattana, K., Nuanchuen, W. and Usawang, S. (2013) Evaluation of aflatoxin in maize samples feedstuffs by real-time PCR using SYBR Green. Buffalo J., 29, 45-49.

19. Somashekar, D., Rati, E.R., Chandrashekar, A. (2004) PCRrestriction fragment length analysis of aflR gene for differentiation and detection of Aspergillus flavus and Aspergillus parasiticus in maize. Int. J. Food Microbiol., 93, 101-107.

20. Konietzny. U. and Greiner, R. (2003) The application of PCR in the detection of mycotoxigenic fungi in foods. Braz. J. Microbiol., 34, 283-300.

21. Anbazhagan, D., Mui, W.S., Mansor, M., Yan, G.O., Yusof, M.Y. and Sekaran, S.D. (2011) Development of conventional and real-time multiplex PCR assays for the detection of nosocomial pathogens. Braz. J. Microbiol., 42, 448-458.

22. Heid, C.A., Stevens, J., Livak, K.J. and Williams, P.M. (1996) Real time quantitative PCR. Genome Res., 6, 986-994.

23. Fittipaldi, M., Codony, F. and Morato, J. (2010) Comparison of conventional culture and real-time quantitative PCR using SYBR Green for detection of Legionella pneumophila in water samples. Available From: http://www.wrc.org.za.

24. Morrison, T.B., Weis, J.J. and Wittwer, C.T. (1998) Quantification of low-copy transcripts by continuous SYBR Green I monitoring during amplification. Biotechniques, 24, 954-958.

25. Ririe, K.M., Rasmusses, R.P. and Wittwer, C.T. (1997) Product differentiation by analysis of DNA melting curves during the polymerase chain reaction. Anal. Biochem., 245, 154-160. 